\title{
When the Grass Stood Stirrup-High: Historical Fact or Urban Myth?
}

\author{
By David Bradford
}

$\mathrm{T}$ here are numerous stories of North America as it existed before European settlement. These stories often describe a virtual Garden of Eden. It has become conventional wisdom in popular American culture that European immigrants had a profoundly destructive impact on the North American landscape and that the indigenous peoples lived in perfect harmony with the land. These popular perceptions are often carried into discussions on natural resource management, including timber management, range management, and fire management. How accurate are these legends? Are they based on accurate, historical facts, or are they based on speculative, often erroneous assumptions?

\section{Fact or Myth?}

One such story concerns the salt deserts of western Colorado. These desert areas are known locally as the "adobies" (Fig. 1). The tradition is that these areas once supported "stirrup-high" grasslands. For those unfamiliar with the legend, the following description is from an article titled "The 'Dobes come alive" published in the Sunday Denver Post on December 24, 2000:

In the arid West, where the signs of ravage stand out as plain as a rash on a bald man's head, my list of ugly and useless landscapes included mining-scarred mountains, clear-cut forests and over-grazed rangelands. When I moved to Western Colorado a decade ago, I encountered a perfect addition: the 'Dobes.

Save for a mangy assortment of dull-colored shrubs and exotic grasses, the series of lowslung hills sprawl like a moonscape between
Hotchkiss and Delta, including the Adobe Buttes west of Orchard City. Around here, we just call them the 'Dobes (pronounced "dobeys").

A wet spring will green up the 'Dobes for a few weeks, but even then the gauzy vegetative covering seems as insubstantial as cheap lingerie. During rare storms, their namesake clay adobe soils turn into impassable gum.

In town I heard a local legend that backed my suspicions: the 'Dobes weren't always the 'Dobes. Stirrup-high grasses covered the hills in the times when the Ute Indians still traveled through the area. At the turn of the century, however, cattle ranchers turned loose their immense herds. Within a few years, the grass was gone, apparently never to return.

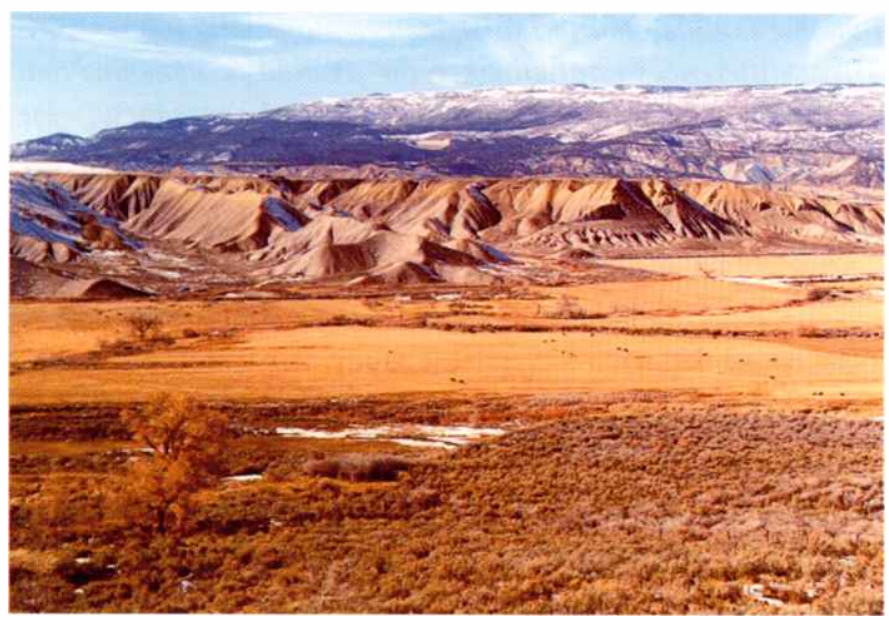

Figure 1. View of adobe badlands, irrigated fields, black greasewood, and sagebrush slopes along lower Tongue Creek south of Cedaredge, Colorado. The Grand Mesa is on the skyline. This photograph shows the complex geology and geography of western Colorado (Erica Gabehart, 1997, courtesy Delta County Independent). 

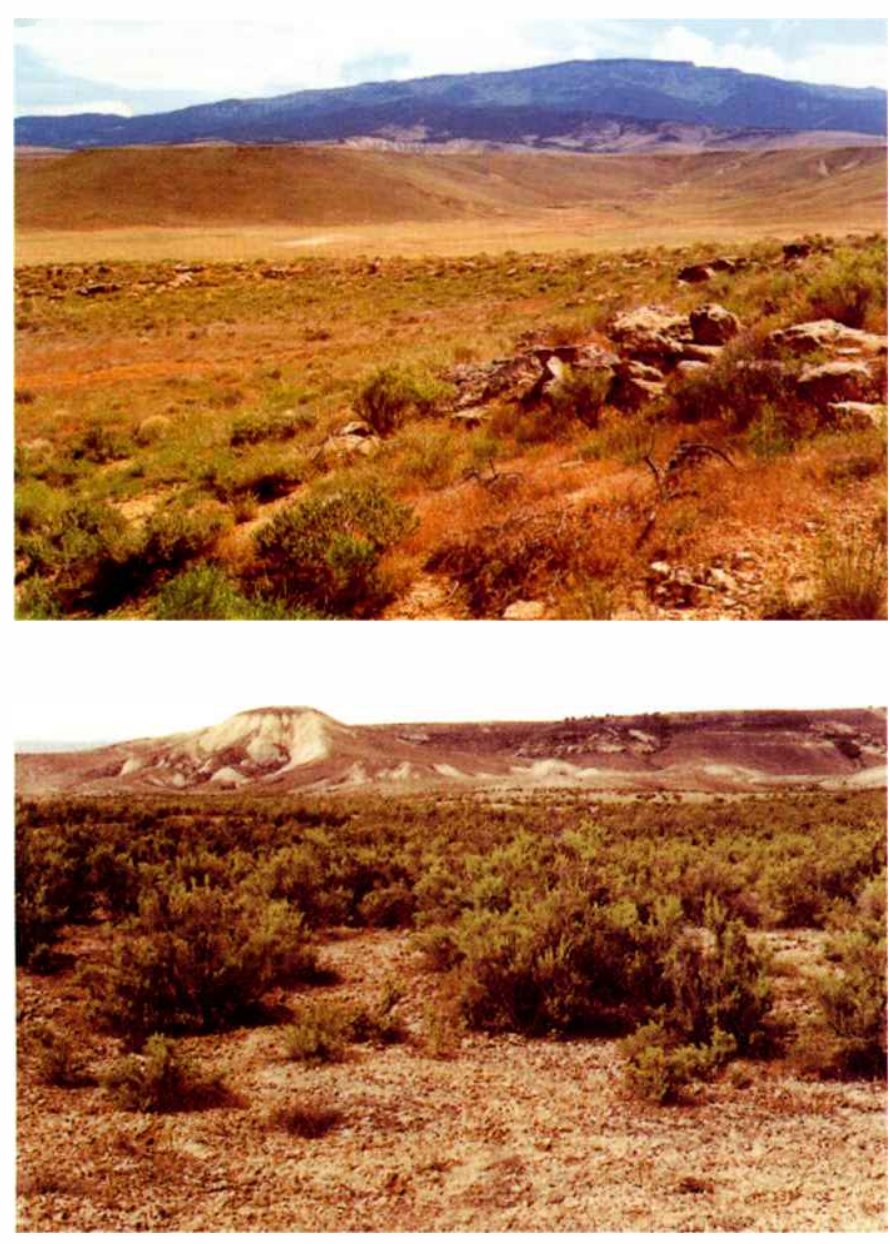

Figure 2. Adobies along Highway 50 between Delta and Grand Junction, Colorado (David Bradford, U.S. Forest Service). Adobies between Delta and Hotchkiss, Colorado, dominated by black greasewood. While the adobies appear uniformly desert-like, there is considerable microsite variation due to differences in soils, aspect, slope, and topography. These differences can influence the amount of moisture that actually is available to plants on a site and consequently the plants that grow on the site. These 2 photos display those differences.

This legend is widespread. There are also numerous local histories written over the past 50 or so years that make these same claims. When I first moved to western Colorado, I too was told this story. I was working on a grazing allotment that included several thousand acres of adobe badlands, and we were trying to describe our desired future condition for this area. The story of the stirrup-high grass seemed remarkable to me as this area receives less than 8 inches of precipitation annually-with only 4 inches falling during the growing season (Fig 2). Eventually, I began a re- search effort to determine if there were any written descriptions of the area that pre-dated American settlement. These efforts led to a journey through the past. I reviewed over 150 different publications from over a dozen institutions, including local, state, and national libraries and museums that contained information on the Uncompahgre Basin and the North Fork Valley. This journey into the past culminated in the discovery of over 200 historic landscape photographs, taken from 1883 through 1916. These photographs came from a variety of sources-the U.S. Geological Survey, the U.S. Forest Service, the National Archives, the Denver Public Library-Western History Collection, local historical societies, and individuals. Is there historical documentation to support the claim of stirruphigh grass? The following descriptions are several of the firsthand accounts of the Uncompahgre Basin and North Fork Valley prior to American Settlement.

\section{Spanish Exploration}

The earliest documented Spanish presence in western Colorado was that of Don Juan Marie Antonio Rivera in 1765. Rivera led 2 expeditions into western Colorado. The first expedition set out in the summer of 1765 . The purpose of the expedition was to determine if there were silver deposits in the area. While Rivera did not discover significant silver deposits, the mountains where these deposits were supposed to occur became known as the Sierra de la Plata-a name that is still in use today. Rivera also learned that a great river was located just to the north of the area. The Spanish were interested in this river, as they hoped it was the Rio del Tizon, today's Colorado River. This had become important to the Spanish, as they were interested in locating an overland route that would link the New Mexico colony with the newly established colonies on the California coast-Los Angeles, Monterey, San Diego, and others. They hoped the river would provide that route. Rivera returned in the fall of 1765 on a second expedition to investigate. The journals of Rivera provide some descriptions of the landscapes of western Colorado. However, research on the expeditions of Rivera is limited, and the specific locations have not been identified. 


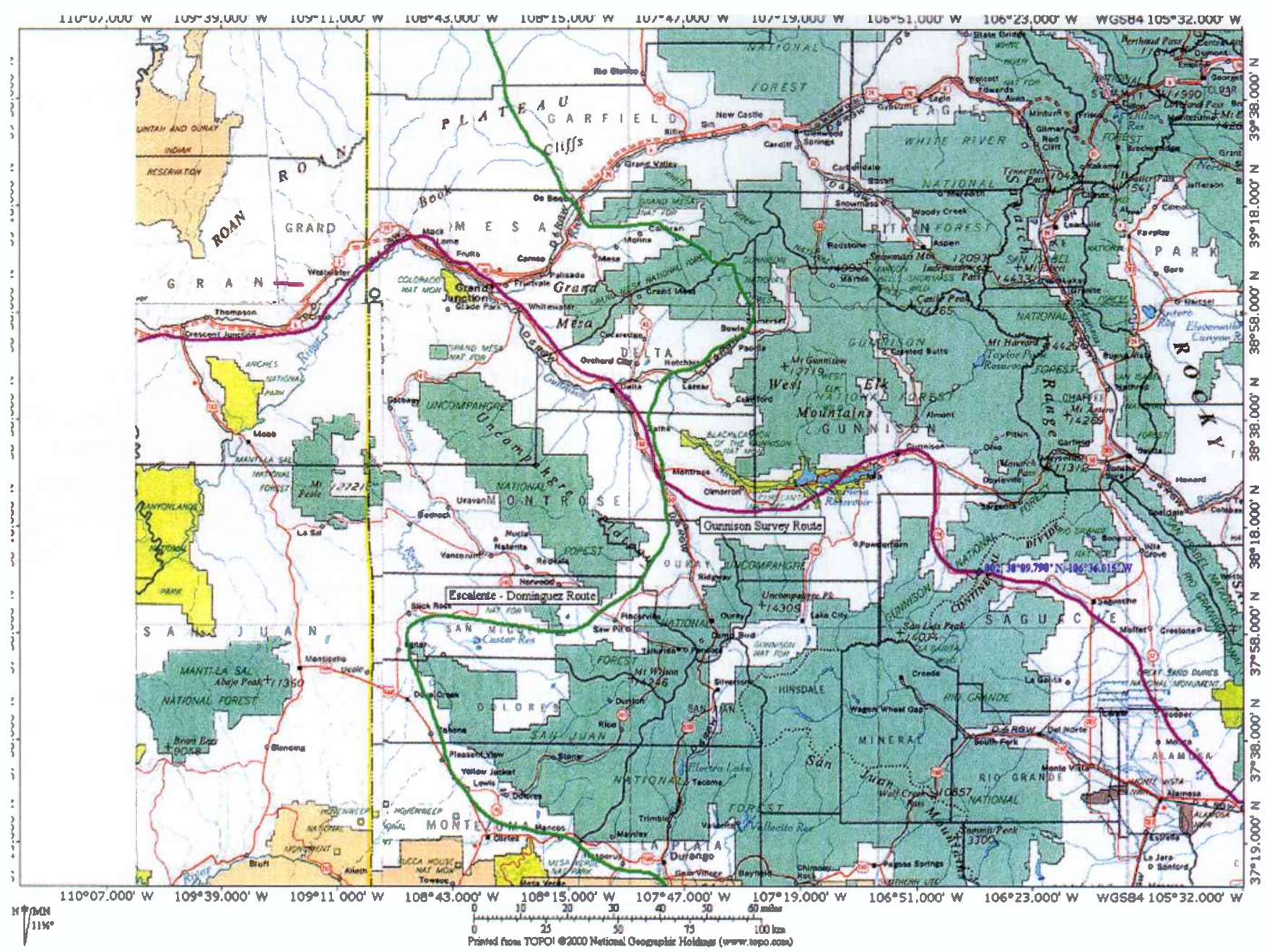

Figure 3. Routes of the Escalente-Dominguez and Gunnison expeditions.

Probably the most famous of the Spanish explorations into western Colorado was the Escalente-Dominguez expedition of 1776 . The Escalente-Dominguez expedition was an attempt to locate an overland route from the province of New Mexico to the province of California. The expedition consisted of a small group, 14 people, and the necessary livestock. The group left Sante Fe in July 1776. They traveled through northwestern New Mexico to southwestern Colorado. Escalente and Dominguez crossed the Uncompahgre Plateau into the Uncompahgre Basin, then traveled up the North Fork, where they finally crossed the Grand Mesa (Fig. 3). Escalente documented the journey in a journal. The journal that Escalente produced has been translated several times and studied at length, and the route they followed has been mapped out. These journal entries provide the first verified written descriptions of the Uncompahgre Basin and the
North Fork prior to European or American settlement. The group reached the Uncompahgre River on August 26, 1776, at a site that is on the south side of the city of Montrose. The explorers called the river the Rio de San Francisco, although Escalente noted that the Utes called it the "Ancapagari." At this point, Escalente begins describing the land in the Uncompahgre valley:

The said Rio de San Francisco is medium sized and a bit larger than the Dolores. It is composed of several rivulets which come down the western flank of La Sierra de las Grullas [today's San Juan Mountains] and run northwest, according to what we saw. Here it has a meadow of good land for farming with the help of irrigation. It must be three leagues in size. There is all the rest needed for establishing a good settlement on it. Northeast of 


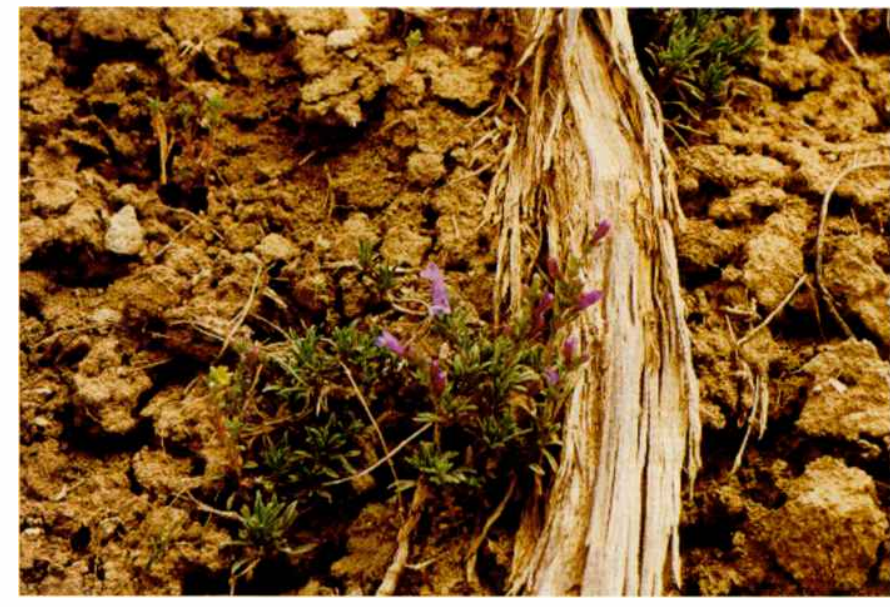

Figure 4. Adobe penstemmon (David Bradford, U.S. Forest Service). Adobe penstemmon is considered sensitive in the salt desert areas of western Colorado. It is an endemic to the area, being closely tied to the Mancos shale or adobe soils.

this meadow there is a chain of small mounts and hills of a leaden color crowned with yellow ochre earth.

On August 27, 1776, the group traveled north, camping at a site near the modern town of Olathe. They called the campsite "La Vega de San Agustine." Escalente described the expedition's journey that day:

We continued our day's march through the meadow and, after trekking two leagues and a half to the northeast, crossed the river and dense leafy grove of poplars and other trees which its banks bear hereabouts. We went up a small incline, entered a plain of no pasturage but of very minute stone and, after going all the way downstream for three and a half leagues [approximately eight miles] northwest, halted on another meadow of the same river, which we named San Agustin [this site is approximately 2 miles north of Olathe]. It is larger and has on either side of it abundant pastures and a great deal of black poplar.

On August 28, 1776, the group continued traveling north through the Uncompahgre Basin. They arrived at the banks of the Gunnison River, just east of Austin, Colorado:
On the 28th we set out northward from the La Vega de San Agustin, already leaving El Rio de San Francisco, and after half a league of travel we continued three leagues and a half north-northeast over loose dirt and without stone and arrived at the already mentioned Rio de San Francisco Xavier-Tomichi by another name-which is made up of four little rivers coming down from the northernmost point. It is as bounteous in water as El Norte, runs west, and at the western point of La Sierra del Venado Alazan it joins the San Francisco, as we already said. Its banks hereabouts are very sparse in pasturage. By a bend of it, where we found some pasture for the mounts and named it Santa Monica, we stopped today with the intention of resting awhile.

The Escalente journal provides the first written descriptions of the landscapes of the Uncompahgre and North Fork valleys. These descriptions portray considerable variety in the vegetation on the landscapes. The land in the basin is mostly lacking grass, and the only sites where pasture for the livestock can be found is along the rivers. As the expedition moved up the North Fork Valley, this general pattern continued, although the group did begin crossing through areas of prickly-pear cactus and sagebrush. As the group moved into the upper North Fork, they began to find junipers and oak brush. As they moved onto the Grand Mesa, they finally found abundant pastures, with aspens and spruce forests common.

\section{American Military Exploration: 1850-1873}

Following the acquisition of California and the Southwest through the 1848 Guadeloupe Hidalgo Treaty for the American-Mexican War of 1846-1848 and of Oregon through the Oregon Boundary Settlement of 1845 with Great Britain, the United States began to consider how to link the East and West Coasts. The advent of railroad transportation provided the answer to the type of transportation needed. The location of the first transcontinental railroad became an issue in a great national debate. The controversy developed because of the huge potential economic benefits that would be 
generated by the railroad. The dispute waged for years. By early 1853 , the Congress, in an attempt to find a solution to the location of a transcontinental railroad, authorized a governmental survey of all the proposed principal routes to decide which was the "most practicable and economical." These surveys were placed under the direction of the secretary of war, Jefferson Davis. Davis established 4 different surveys led by various members of the U.S. Army Corps of Topographical Engineers. These 4 surveys became known collectively as the Pacific Railroad Survey. Captain John W. Gunnison was directed to explore the route along the 38th and 39th parallels of north latitude, a route that ran from St. Louis, Missouri, to San Francisco, California. This route would follow the Arkansas River to the front range of the Rockies, over into the San Luis Valley, across the central Rockies to the Uncompahgre Valley, and down along the river valleys into Utah and on across to California.

Each survey was required to complete a report. These reports were to provide the Congress the information to make a decision on this controversial issue. Gunnison's journal entries kept track of topography, vegetation, and basic geology-information that would be needed to determine the practicability and cost of building a railroad along this route as well as the feasibility of future settlements, an important consideration for railroad business. The report of the expedition, completed by Lieutenant E. G. Beckwith (1855) because of the death of Captain Gunnison in Utah, provides excellent descriptions of the lands that the expedition crossed in 1853.

The Gunnison Survey was composed of a survey party of 8 men with a military escort of 32 soldiers; to carry the equipment and material, there were 18 wagons with teamsters for a total of 58 individuals. The expedition used 104 mules for the wagons, at least 40 horses, and additional livestock for the survey and military party. The expedition departed from Fort Leavenworth on June 25, 1853. The going was slow and difficult, especially when they reached the mountains, because of the heavy and cumbersome wagons.

By September 15, 1853, the expedition reached the Uncompahgre Basin. The expedition traveled along Cedar Creek in the southeast corner of the basin
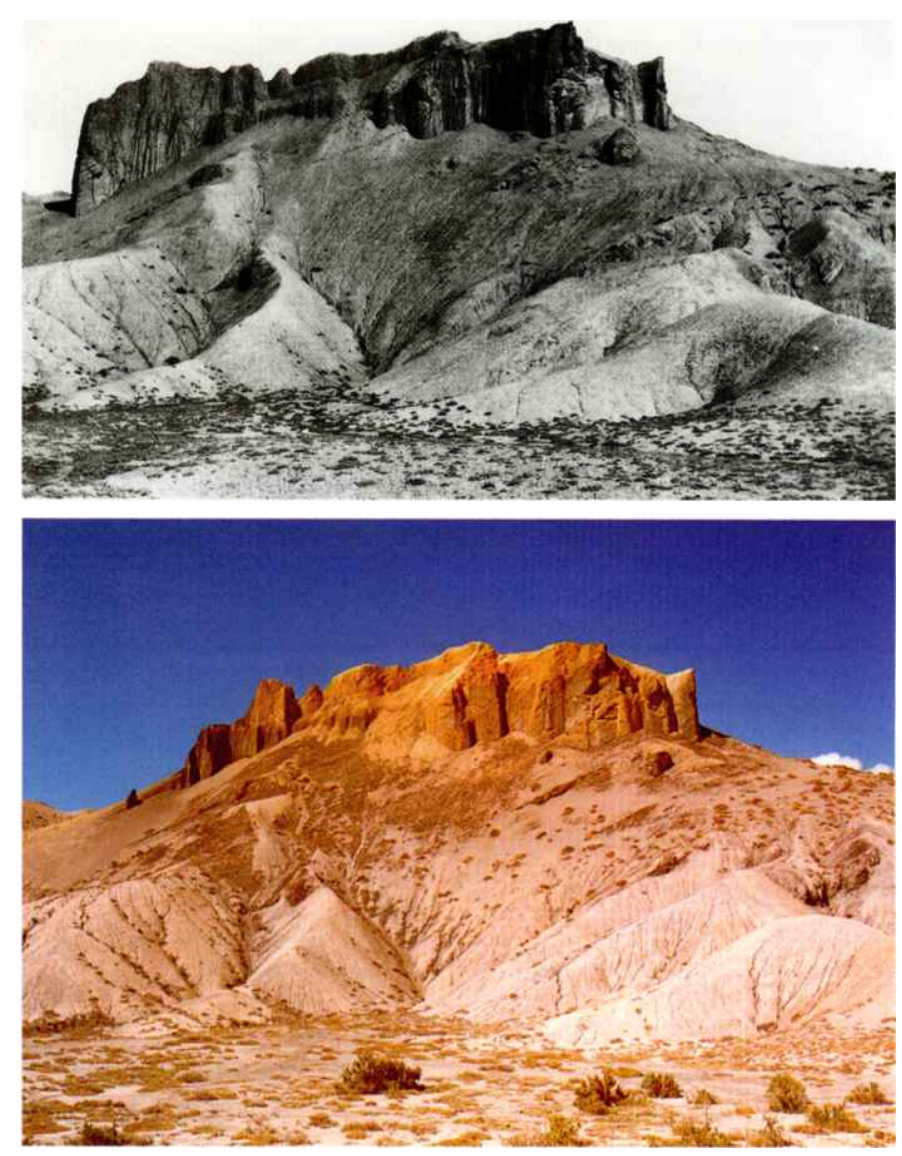

Figure 5. View of shale outcrop northeast of Adobe Butte, between Cedaredge and Delta, Colorado (Willis T. Lee 1907 U.S. Geologic Survey; David Bradford 9-27-2002 U.S. Forest Service). This photo comparison shows natural erosion occurring in the shale outcrops and little change in vegetation.

down to the Uncompahgre River (Fig. 3). The following excerpts from the report of the Gunnison Pacific Railroad Survey describe the landscapes that the expedition members viewed as they traveled through the Uncompahgre Basin to the Grand Valley:

To this point the cacti and sage were troublesome, but were scarcely seen again until we reached the borders of the Uncompahgra; the hills and valley alike on each side of our route, being a light-colored, friable and clayey soil, almost destitute of vegetation. The valley of the Uncompahgra, efflorescing with salts in many places, is several miles in width, and the stream is lined with cotton-wood trees, willow, and buffalo-berry bushes, and, by crossing it where it was thirty feet wide by one deep, we 

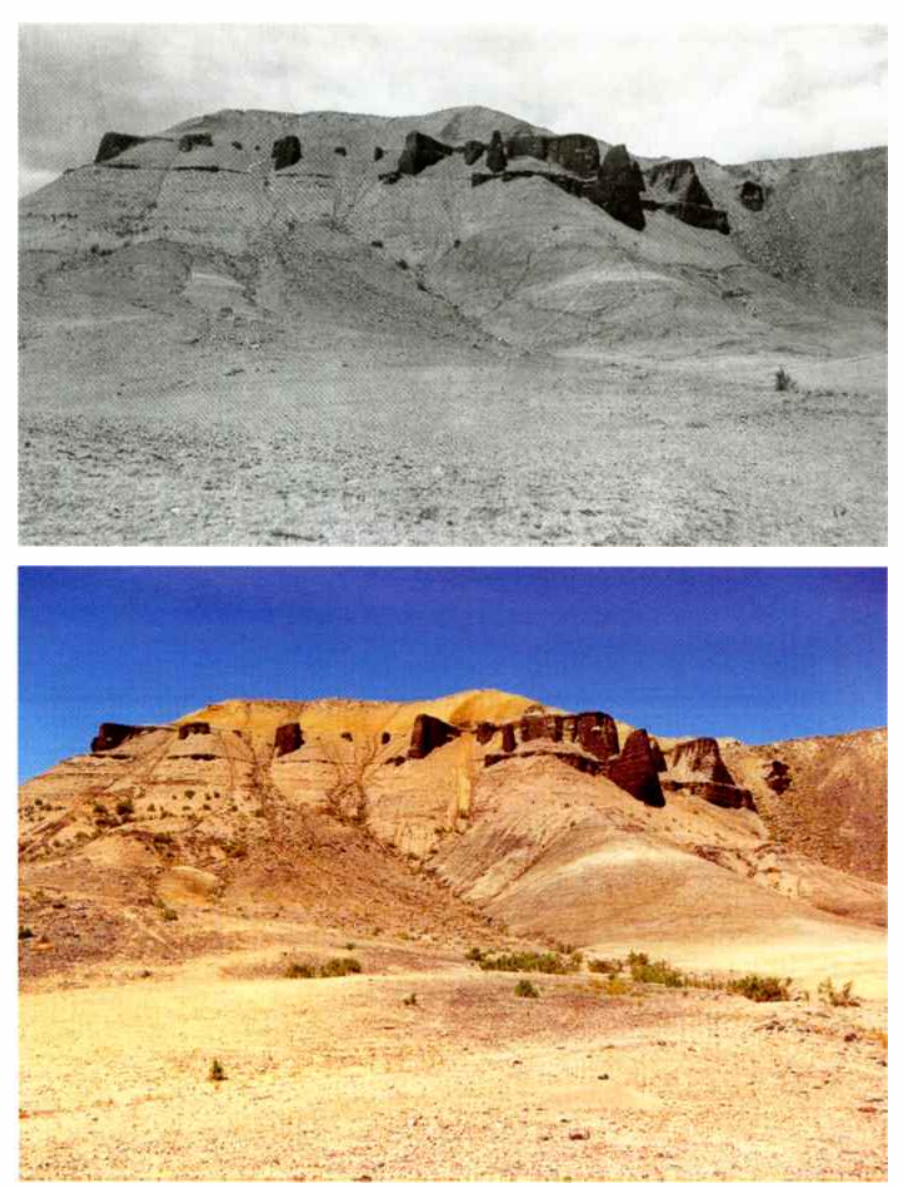

Figure 6. View of shale outcrop along U.S. Highway 50, northwest of Delta, Colorado (Willis T. Lee, 1907 U.S. Geologic Survey; David Bradford May 8, 2001, U.S. Forest Service; David Bradford, June 1997, U.S. Forest Service). Lee noted in 1907 "the barrenness of the shale slopes." Little has changed over the past 90 years.

found an abundance of grass and encamped, having marched 12.30 miles, descending 87.7 feet to the mile for the last ten miles.

September 16, 1853. . . We traveled 18.25 miles down the Uncompahgra to-day, crossing the stream four miles below our morning camp, and again a few miles before encamping this evening, a short distance above its junction with Grand River; the descent from camp to camp slightly exceeding forty-one feet to the mile. The country is in all respects like that passed yesterday-cotton-wood, willow and grass in the narrow bottom, and near it heavy sage; but the great mass of the valley land is nearly destitute of vegetation-light, clayey and arid to such an extent that it is disagreeable to ride over it, as it sends up clouds of dust at every step.

From this point, the Gunnison expedition moved on into what is today's state of Utah. Tragedy struck the expedition on October 26, 1853, when Paiute Indians attacked part of the party and killed Captain Gunnison and 7 others. Lieutenant Beckwith took command of the expedition and led it for the remainder of the journey. The Pacific Railroad Survey, when completed, did not provide the final answer to the location of the national transcontinental railroad. The results of the survey continued to be debated with the various factions splintered along ideological lines. The issue of slavery caused such a division in the country that no agreement could be reached on whether the route should be placed in the North or the South. Each side worried that the railroad would give the other a major tactical advantage. As a result, the first transcontinental railroad was not built until after the Civil War began.

The descriptions of the Uncompahgre Valley and lower Gunnison River in Beckwith's report provide a clear picture of these lands in 1853. Rather than finding stirrup-high grass, the expedition struggled to find camp locations with sufficient forage for the expedition's livestock. The next detailed survey of the area occurred in 1873-1875, just prior to the opening of the area to American settlement.

\section{American Scientific Exploration: 1874-1881}

American settlement began in the central Rocky Mountains in 1859, when gold was discovered on Cherry Creek on the plains just east of the Rocky Mountains. American miners poured into the mining districts as new deposits were located. The area was politically part of the territories of Kansas and Utah. As American development increased in the West, there were increased pressures on the U.S. government to assist in that development. To determine what resources the West held, the Congress established a number of scientific surveys. While a number of these surveys worked in Colorado, the primary survey that investigated Colorado was the Hayden Survey (1876). Officially, this survey was 
known as the United States Geological and Geographical Survey of the Territories. Ferdinand Vandiveer Hayden led this scientific survey. Hayden began survey work in Nebraska in 1867. He directed survey work in Nebraska and Wyoming before moving the survey into Colorado in 1873. The Hayden Survey explored Colorado and mapped the geology, geography, and vegetation from 1873 to 1875. Hayden published the results of his fieldwork on an annual basis, so the reports of the Uncompahgre Basin, North Fork Valley, and surrounding area are found in 2 separate reports: the Eighth and Ninth Annual Reports of the United States Geological and Geographical Survey of the Territories. These reports include 12 sections written by different authors. The 12 sections include reports on geology, paleontology, archaeology, zoology, topography, and mining.

The following description of the Uncompahgre Basin is an excerpt from the Eighth Annual Report of the United States Geological and Geographical Survey of the Territories Embracing Colorado and Parts of Adjacent Territories; Being a Report of Progress of the Exploration for the Year 1873:

Description of the Uncompahgre BasinCedar Creek is probably dry during the greater part of the year. It rises in a plateau-like divide, opposite a small branch of Cebolla Creek, a few miles west of the mouth of the main stream. Its general course is about northwest. The upper portion of the valley is narrow and ravine-like, the slopes of the hills being covered with scrub-oak, sage, and cactus, with here and there patches of grass. This valley continues for about ten miles, where the creek comes out into the broad valley of the Uncompahgre, which at this point has lines of buttes of light-colored clayey-beds, the debris of which forms a soft soil, in which the mules sink to their fetlocks at every step. All the small creeks, dry for the greater part of the year, cut deep gullies in this soft soil, which is almost destitute of vegetation. In places there is considerable efflorescence of alkali, and gypsum is found abundantly throughout the valley. The buttes are found on the eastern side of the valley. They are from two hundred to four hundred feet high, and form two lines, those nearest the canyon of the Gunnison being the highest. The buttes are not so numerous in the lower part of the valley, where the general level is but a few feet above the river bed. It is more plain-like, without grass, having only a sparse growth of low sage, interspersed with spots of alkali, giving the country a most desolate aspect. Along the river is an alluvial bottom, with good grass, the river being bordered with cottonwoods, willows, and low bushes of various kinds. This bottom becomes much wider as we descend, and is a favorite wintering place for the Ute Indians. We found traces of their camps, while their trails run in every direction. In one place we found a field where corn had been raised, the stalks of which were still standing.

This excerpt from the reports by the Hayden Survey provides a clear, detailed description of the Uncompahgre Basin in the mid-1870s. The Hayden Survey finished in western Colorado in 1876, 6 years before the first American settlers moved into the western slope valleys. This description of the Uncompahgre Basin corresponds closely to those of the Escalente-Dominguez and Gunnison expeditions.

\section{The Adobies}

The historic descriptions raise the question, What are the adobies? What caused these stark landscapes to form? Geologists consider western Colorado to be on the western edge of the southern Rocky Mountains and the eastern edge of the Colorado Plateau. The setting is a stark and dramatic landscape of arid, almost desolate valleys surrounded by 5,000 - to 9,000-foot-tall mountains. This complicated looking landscape is complex. The geology and topography strongly affect climatic conditions and plant growth in ways that are not apparent at first sight.

The Uncompahgre Basin and the North Fork Valley were created over the last 100 million years by complex orogenic and hydrogeologic processes. These processes created a very diverse landscape. 
The Uncompahgre Basin is a northerly trending valley that is surrounded by mountains on nearly all sides. The North Fork Valley lies to the east and is separated from the Uncompahgre Basin by a geologic uplift called the Black Canyon of the Gunnison River. It, too, is surrounded by mountains, except for the gap through which the North Fork River flows. The North Fork enters the Uncompahgre Basin on the northeast. The bottomlands of both the basin and the valley are formed from sedimentary deposits laid down 100 million years ago at the bottom of an inland sea. These deposits are predominantly clays and shales and are very saline. These gray, black, and tan-colored deposits were named the Mancos shales by geologists and are known locally as the "adobies" or "dobies." The seas retreated 40 million to 70 million years ago, and the area became freshwater marshes. During this period, a series of sedimentary deposits that are a mixture of sandstones, shales, and conglomerates were formed. These sedimentary deposits are located above the adobies. These layered rocks are tan to white to red colored and have a courser texture than the adobies. From 70 million to 10 million years ago, a series of mountain-building processes pushed 4 different ranges up through these sedimentary deposits. The Uncompahgre Plateau pushed up, to the west. The West Elk Mountains, on the east, and the San Juan Mountains, to the south, were created by a series of volcanic events. The Grand Mesa, on the north, was formed by a combination of volcanic flows and geologic uplift. All these formations were further modified by erosion and glaciation. These geologic processes created a topography that varies from 5,000 feet in elevation in the valley to over 14,000 feet at the highest mountaintops. This varied topography strongly influences local climatic conditions. Precipitation can vary from 5 inches in certain rain shadows in the basin and valley to over 40 inches in some of the mountain areas. These basic geologic formations and the climate strongly affect the type and amount of vegetation that will grow on a particular piece of ground.

\section{Conclusions}

These 3 accounts provide clear descriptions of environmental conditions in the Uncompahgre Basin in the 18 th and 19 th centuries. It is important to note that all 3 accounts were made independently but are consistent in the descriptions of the land. In contrast, I could find no firsthand historical accounts that provide any evidence that the Uncompahgre Basin supported stirrup-high grass at any time over the past 250 years. I submit that the legend of stirruphigh grass in the adobe badlands is an urban myth.

So where did the theory of stirrup-high grass in the adobies originate? It does not seem possible to say with any certainty. There is some evidence that as more settlers moved into the area conflicts developed between grazers and homesteaders-as it did in many other places in the West. Perhaps this conflict led to allegations of overgrazing and environmental decline. Whatever the basis for the claim, there is no historical evidence to support the contention that stirrup-high grass ever existed in the adobies. It is also important to note that the historical descriptions correspond to the physical characteristics of the land. A landscape that receives 4 to 10 inches of precipitation a year can be expected to produce only a limited amount of vegetation.

History is the branch of knowledge dealing with past events. As the recent historian Stephen Ambrose (2002) stated, "It is through history that we learn who we are and how we got that way, why and how we changed, why the good sometimes prevailed and sometimes did not." I believe this type of historical assessment can provide a factual basis for discussing human impacts to the natural environment. It should provide a better understanding of the potential of the land. Early settlers tended to call the adobe badlands "wastelands." Considerable effort has gone into "reclaiming" many of these lands though irrigation projects over the past 100 years. Obviously, these efforts made the land more productive. However, not all these desert lands are suited for improved management. Many of these lands are highly saline and cannot be irrigated without causing salt accumulations or selenium leaching into the rivers. However, they do have value in and of themselves as wildlife habitat, livestock grazing, and open space (Figs. 4 and 7). Misperceptions on the potential of these lands can lead people to believe the lands are "trashed" and are suited only for off-road vehicle recreation or dump sites or 

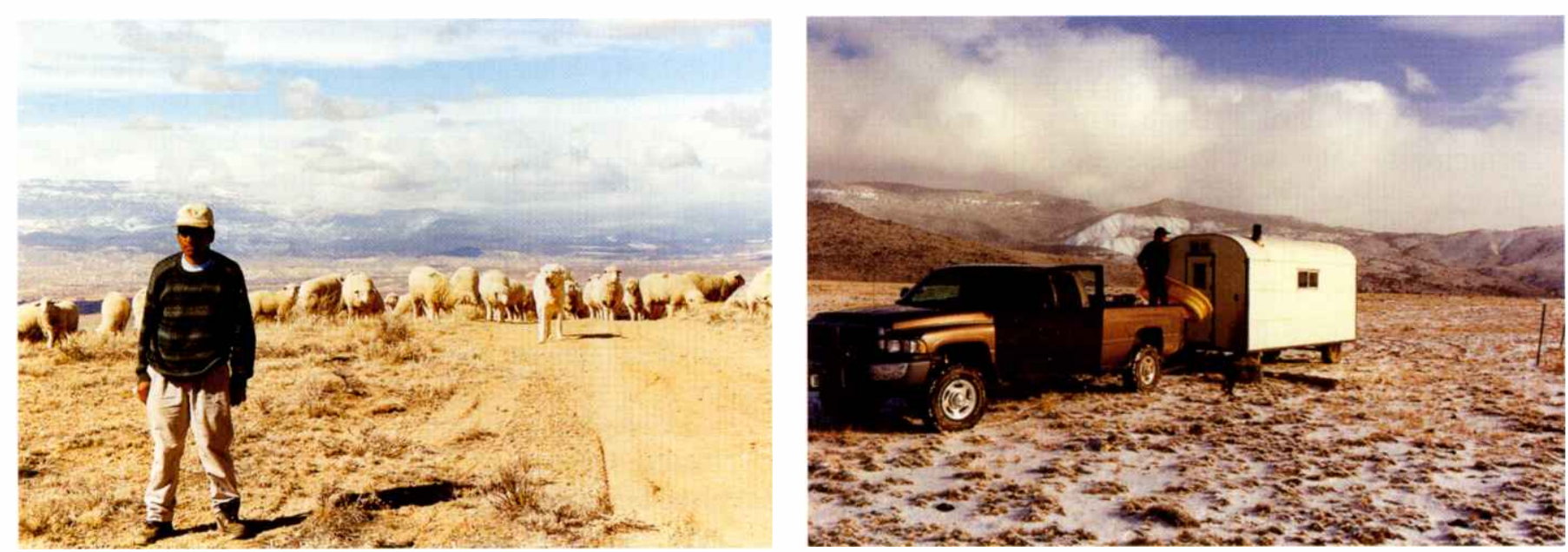

Figure 7. Grazing sheep in the winter in the adobies of the Uncompahgre Basin (Justin McConkey, U.S. Forest Service). Left photo shows a herder, with an Akhbash guard dog, and sheep in the adobies. Sheep graze the various shrub species during the dormant season. The right photo shows the camp tender moving the herder's camp wagon and bringing supplies to the herder and sheep. Sheep will use snow if it is available; if water or snow is not available, the camp tender will have to haul water to the sheep.

perhaps lead one to attempt to "restore" the land by plowing it and planting "improved" species.

Will this information satisfy everyone? Past experience indicates probably not. Bias, paradigms, and prejudice can be obstacles to learning. Nonetheless, I believe this information can clear away many misunderstandings due to a lack of knowledge. I am a third-generation Coloradoan. I was raised by family that has lived here since the 1890s, and I was educated in this state. Yet nearly all the information I found doing the historic research was new to me. It is no wonder that the millions of people who have moved to the West in the past 10 years have little or no understanding of our landscapes and the conditions that formed them. The public will readily accept the information provided to them in the popular media, whether it is fact, speculation, or hyperbole. As our population grows and more people move to the West, it becomes increasingly important to provide them with accurate information on the potential of our western landscapes. The better they understand the land, the better they can understand our decisions. At this point, it should be obvious, this type of information is also critical for us as land managers as well. Our decisions on resource management can only be as good as the information on which we base those decisions.

I believe this type of review is possible for many parts of North America. There is considerable his- toric documentation that we natural resource managers often ignore. The early European and American explorers, the American military, and the early American scientific surveys left a trove of information on environmental conditions of the areas they explored. I suggest that studying this information can help us view the land with better understanding as well as appreciation. The historic documents and photographs I have located are providing factual baseline information on environmental conditions and the historic range of variability for many of the landscapes in western Colorado. We are in the process of completing a publication on these lands. I have done a considerable number of presentations on this information over the past 3 years. The audiences are enthusiastic and appreciative of this factual information.

The Uncompahgre Valley and the North Fork Valley are scenic and desirable places to live. If you look across either valley at any of the spectacular mountains that surround us, you will see the same views that the members of the various expeditions saw as they traveled through these valleys from 1776 to 1875. The vegetation on the landscape looks remarkably like that which Henry Gannett described in the Eighth Annual Report of the Hayden Survey of 1873:

The stream bottoms, up to a height of at least 8,000 feet, produce abundantly cottonwoods 
and grass. The soil is deep and rich, and there is abundant moisture. The lower bench-land, up to a height of fully 8,000 feet produces principally sage and greasewood, pinyon pine, yucca, and cactus, with more or less bunchgrass. The soil is gravelly, or an alkaline clay, dry and arid. The upper benches and lower mountain slopes are covered with scrub oak, pinyon pine, wild service-berry and other bushes. This kind of vegetation is found at elevations from 7,000 to 10,000 feet above sealevel. The soil is quite dry, though not as dry as the last. From 10,000 to 11,000 or 11,500 feet, i.e. to timber-line, on the mountains and plateaus, the characteristic vegetation is pine and spruce, with excellent grass. At these high altitudes the soil is well watered.

I hope this review will help us to view the stark and dramatic landscapes of the Uncompahgre Basin and North Fork Valley with a better understanding and appreciation. This is truly a magnificent place.

Author is rangeland management specialist on the Paonia Ranger District, Gunnison National Forest, P.O. Box 1030, 403 North Rio Grande Avenue, Paonia, CO 81428 .

\section{References}

Ambrose, S. E. 2002. Personal reflections of an historian. New York, NY: Simon \& Schuster, 2002.

BECKWITH, E. G. 1855. Reports of explorations and surveys, to ascertain the most practicable and economical route for a railroad from the Mississippi River to the Pacific Ocean, 1853-54. Volume II. 1855. Report by E. G. Beckwith, Third Artillery, upon the Route near the 38th and 39th Parallels, explored by Captain J. W. Gunnison, Corps Topographical Engineers. Published as 33rd Congress, 2nd Session, House of Representatives, Executive Document 91. Washington, DC: A.O.P. Nicholson Printer.

CARSON, P. 1998. Across the northern frontier: Spanish exploration in Colorado. Boulder, CO: Johnson Books.

CLOCK, L. S. 1983. Cabin and a clothesline: A saga of the North Fork high country and its people. Newell, IA: Bireline Publishing.

Ferrier, M., AND G. Sibley. 1983. Long horns and short tales: A history of the Crawford country, volume 2People.

GoetzMAnN, W. H. 1993. Exploration and empire: The explorer and the scientist in the winning of the American West. Austin: Texas State Historical Association (reprint of 1966 edition).

HAYDEN, F. V. 1876. Eighth annual report of the United States Geological and Geographical Survey of the Territories, embracing Colorado and parts of adjacent territories; being a report of progress of the exploration for the year 1874. Washington, DC: U.S. Government Printing Office.

KRECH, S., III. 1999. The ecological Indian: Myth and history. New York, NY: W.W. Norton \& Company.

MARShALL, M. 1996. Where rivers meet: Lore from the Colorado frontier. College Station: Texas A\&M University Press.

Warner, Ted J., ed., and Fray Angelico Chavez, trans. 1976. The Dominguez-Escalente journal, their expedition through Colorado, Utah, Arizona and New Mexico in 1776. Provo, UT: Brigham Young University Press.

Ubbelohde, Carl, Maxine Benson, and Duane A. Smith. 1995. A Colorado history. 7th ed. Boulder, CO: Pruett Publishing Company. 